\title{
Organizational Issues in the Agrifood Sector: Toward a Comparative Approach
}

\author{
Claude Ménard and Peter G. Klein
}

International comparisons are increasingly popular in empirical studies of economic organization, financial-market performance, and political economy. Besides providing a broad set of firms and industries to compare, these studies highlight the interaction between the institutional environment-the "rules of the game," such as property rights, the legal system, the political process, and social normsand the organizational arrangements trading partners design to govern their relationships. The "law and finance" approach (LaPorta, Lopez-de-Silenas, and Shleifer) suggests that the origin of a country's legal system (English Common Law, French Civil Law, and so on) largely explains the organization and development of financial markets and corporations, though the relationship may be more subtle and complex than originally thought (Roe). Similarly, recent studies of contracting and regulatory practices find that implementation and performance of comparable contractual arrangements vary systematically with a country's political and legal systems (Levy and Spiller, Shirley and Ménard).

The comparative approach can also be usefully applied to organizational change in food and agriculture. Recent U.S. trends, such as consolidation, vertical integration, and the emergence of new network organizations, are also observed in Europe and the developing world. Comparing the nature, causes, and consequences of these trends across countries helps us see what forms of organization are

\footnotetext{
Claude Ménard is professor and director, Center for Analytical Theory of Organizations and Markets (ATOM), University of Paris (Panthéon-Sorbonne); and Peter G. Klein is assistant professor of agribusiness and associate director, Contracting and Organizations Research Institute (CORI), University of Missouri.

The authors thank Jean-Marc Chappuis, Michael Cook, Johny Egg, Fatiha Fort, George Hendrikse, Guido van Huylenbroek, Harvey James, Loic Sauvee, and Michael Sykuta for helpful suggestions. The usual disclaimer applies.

This article was presented at the ASSA winter meetings (San Diego, CA, January 2004). Articles in these sessions are not subjected to the journal's standard refereeing process.
}

feasible, which ones work best under various circumstances, and how legal, political, and social factors affect organizational choice and performance.

This article outlines a research program comparing the economic organization of agriculture in the United States and European Union (EU). While both have highly developed agricultural sectors, there is substantial variation in organizational arrangements between and within the two. History and path dependence explain some of this variety, but other local conditions are important as well. For instance, European farms tend to be smaller than U.S. farms and more tightly interwoven with cities and tourist areas, so European agriculture is more closely tied with local economic, demographic, and cultural issues.

There are also important differences within countries and regions. Growing olives is different from raising livestock. Moreover, variation in the dominant modes of organization between the United States and EU and within the EU are partly responsible for ongoing tensions and policy disagreements over the nature and type of subsidies, the role of regional development, quality control and traceability, food aid to developing countries, and similar issues.

We begin by discussing recent trends toward horizontal and vertical integration. The second section looks at network modes of organization. The third section identifies key issues likely to be important in the coming years, particularly with respect to agricultural policies. Part of the research reported in this article involves our research centers, the Center for Analytical Theory of Organizations and Markets (ATOM) at the University of Paris (Panthéon-Sorbonne) and the Contracting and Organizations Research Institute (CORI) at the University of Missouri. Both centers sponsor interdisciplinary research on the economics of contracting and organizational form in the agrifood and other sectors. 


\section{The Trend toward Integration and Tighter Coordination}

Over the last century, the dominant trend in agricultural production, both in the United States and the EU, has been consolidation. In 1920, the United States had about 6.5 million farms with an average of 149 acres per farm. In 1997, there were fewer than 2 million farms, averaging 487 acres per farm. The European situation is similar: In France, the EU's leading agricultural producer with $21 \%$ of total production in 2000 , there were 660,000 farms that year compared to over 2 million in 1958. The average French farm in 2000 had 104 acres compared to half that area forty years earlier. The processing and distribution sectors are also becoming more concentrated. The twenty largest U.S. grocers had a combined market share of $48.2 \%$ in 1998 , up from $37 \%$ in 1992. The thirty largest European grocers held $68.5 \%$ of the market in 2001, up from $51.5 \%$ in 1992 (French and German companies dominate the top ten with $41 \%$ of the market).

At the same time, farming - unlike virtually every other mature industry-has remained largely a family-owned business. In the United States, corporate farms in 1997 held only $1.2 \%$ of total farm acreage and generated only $5.6 \%$ of total sales receipts. In France, $75 \%$ of farms are family owned with no employees. Allen and Lueck argue that this ownership pattern results from agriculture's unique combination of seasonality and random variation, which makes it difficult to design and enforce effective incentive contracts that minimize moral hazard. Instead, sole proprietorships, with the farmer or farm family as residual claimant, outperform joint ownership arrangements, such as corporations.

The combination of dispersed family ownership and highly concentrated processing and distribution sectors poses unique challenges, particularly with respect to vertical coordination and quality control over the supply chain. Large processors and distributors have shifted from spot-market exchange to contracts and formal negotiating bodies for coordinating the production process. Indeed, the rapid increase in tightly integrated vertical arrangements, such as production and marketing contracts, is one of the most dramatic changes in the agricultural production process in recent decades both in the United States (Martinez and Reed, Royer and Rogers) and in Europe.
Vertical coordination accomplishes several purposes. Processors wish to control their supply chains more tightly to satisfy consumer demands for quality and safety. In the EU, new regulations making large retailers liable for the quality and identity preservation of the food they sell impose a new set of problems that vertical coordination may alleviate. Similarly, new quality certification and grading systems for protecting consumers that have emerged in Europe over the last ten years require tighter coordination. ${ }^{1}$ Contracts and vertical integration may also generate efficiency gains by reducing transaction costs (Frank and Henderson). These objectives can be achieved using a variety of organizational arrangements from vertical integration to production or marketing contracts to formal or informal negotiating arrangements.

In Europe, there is substantial variety among contracts across countries, even within industries. Vertical integration or tight vertical control led by large retailers is largely developed among northern members of EU (U.K., Germany, and the Scandinavian countries). Complex contractual arrangements among hundreds or even thousands of participants are common in France, Italy, the Netherlands, and to a lesser degree Spain, particularly for developing and marketing products of "Protected Designations of Origin" and "Protected Geographical Indications" as well as organic products. Small independent producers that are less coordinated and tend to focus on local or regional markets are common in Southern Europe (Greece, Portugal, and parts of Spain, Italy, and France). ${ }^{2}$

Moreover, we observe many types of contract even within an industry in a particular country, and these contracts appear to serve very different purposes. An extensive study of over 20,000 contracts in the poultry industry in France showed a differentiation among three types of contracts- - fixed-price," "buy-and-sell," and "putting-out" contractsthat clearly related to the degree of specific investments (Ménard). Recent studies on contractual agreements in France and in the

\footnotetext{
${ }^{1}$ Examples are EU regulation 2081/92, defining protected designation and origins, the adoption and implementation of EUROP (European Union Grading System) in the livestock sector, or the recommendations of the EU White Paper on Food Safety (2000).

${ }^{2}$ A collaborative research project on methods for quality control by seven European research groups in as many countries illustrates this variety. See preliminary results in Raynaud, Sauvée, and Valceschini.
} 
EU also show changes regarding the content of contracts (Mazé; Raynaud, Sauvée, and Valceschini). These arrangements involve an increasing number of detailed clauses regarding quality and the control and monitoring processes that render inputs traceable, all of which require increasingly tight control of the supply chain. Interestingly, these contracts are largely imposed by concentrated retailers. ${ }^{3}$

Why the variety in forms of vertical coordination? Within countries, transaction-cost considerations are important. In the United States, for example, virtually all poultry, turkey, and eggs are produced under contract or vertical integration, though precise arrangements vary widely (Martinez). Egg production is highly vertically integrated while poultry and turkey production rely more on production contracts. In France, over $80 \%$ of the growers in the poultry industry operated under contracts in 1994 (Ménard). In the U.S. pork industry, about 72\% of total hogs were sold through marketing contracts in 2001 (Martinez).

These production and transformation processes are all increasingly mechanized and subject to quality standards that require highly specialized equipment. As emphasized in the transaction-cost literature (Joskow, Klein), relationship-specific investments give rise to potential "hold-ups," which are best mitigated through contract or vertical integration. Egg, poultry, and turkey production is characterized by high degrees of physical asset specificity, and, because of perishability, site, and temporal specificity. Because hogs can be transported greater distances without losing value, and can be slaughtered at different ages, site and temporal specificities are less important in the pork industry where (less tightly coordinated) marketing contracts appear sufficient to mitigate opportunism.

The lesson from this brief tour of vertical relationships within the U.S. and European agrifood sectors is that the nature and purposes of particular contractual arrangements can best be understood in comparison with alternative arrangements observed in other industries, countries, and regions. Comparisons should also allow better understanding of why some modes of organization are better adapted to certain transactions and how institutional factors affect the choice of organization.

\footnotetext{
${ }^{3}$ The development of a database on contracts at CORI and a similar (but smaller) initiative at ATOM should help facilitate longitudinal and cross-country analysis. On the CORI contracts collection see Sykuta and James.
}

\section{Trend toward Network Organizations}

Collaborative or network organizations, such as cooperatives, joint ventures, and other "hybrids," have always been important in U.S. and European agriculture. However, network organizations among farmers and among participants to vertically coordinated supplychain systems have become increasingly important in Europe during the last twenty years. As the term "hybrid" implies, network organizations represent a blend, or compromise, between the benefits of centralized coordination and control and the incentive and informational advantages of decentralized decisionmaking. While network members pool significant resources, they often rely on relational contracts, rather than formal written agreements, though they do establish some formal mechanism for coordination.

Two complementary factors may explain the rapid development of network organizations, particularly in the EU. First, European agricultural policy over the last half century was designed to achieve restructuring while retaining family ownership. Along with the major concentration in distribution, this dispersed ownership puts the coordination problem at the center of organizational issues. Second, European consumers have increased dramatically their demands for quality certification. The certification movement began in France in the early 1960s with small group of poultry producers and took off during the late 1970 s. For instance, the high-quality segment of the poultry industry (the "red-label" system) represented over $30 \%$ of the French poultry market in 1994, up from $2 \%$ in the late 1970s (Ménard). This system, made up of a tightly coordinated group of producers, spread quickly to the pork and beef sectors and diffused to other European countries (particularly, Italy and, to a lesser extent, the Netherlands and Spain). This evolution was formally endorsed by the adoption in 1992 of a certification system by the EU (Regulation 2081/ 92). In other European countries, quality certification has also become more important but is handled by private firms (brand-name certification) or quasigovernmental organizations, such as the British "Meat and Livestock Commission."

As was the case with vertical coordination, we observe substantial variety in how these networks are organized. Three stylized types are identifiable. First, some networks are organized around a leading firm. The leader is 
often a large processor coordinating and monitoring a vast network of suppliers, eventually spread over different countries with different regulations and institutions. To manage these contracts while guaranteeing regularity and quality of supply and maintaining adequate incentives for producers, leading firms tend to rely on a stable network of producers. We see this model both in the United States (Knoeber) and in the EU (Sauvée).

A second, more "egalitarian," form of network groups a large number of participants with similar rights and duties. The firms that developed the red-label system in France are a good illustration. To guarantee quality, reduce contractual hazards, and prevent free riding among legally independent partners, mechanisms must be designed to monitor the partners. Coordinating structures tend to emerge with significant authority on the parties (Ménard), such as Loué in the European poultry industry or Saveol in the market for high-quality tomatoes.

The traditional U.S. producer's cooperative is another type of network organization. Even here, however, there is considerable variety and change. Traditionally organized cooperatives, characterized by open membership, nontransferable ownership shares, and a narrow product scope suffer from what Cook calls "vaguely defined property rights," resulting in various conflicts of interest among members. "New generation" cooperatives attempt to solve these problems by restricting membership, allowing transferability of equity shares, and diversifying the organization's product line. Alternatively, rearranging certain ownership rights within the traditional cooperative structure can help improve members' investment incentives (Hendrikse and Bijman).

The last decade or so has seen an explosion of interest in the development of these nonstandard modes of organization in agrifood networks, particularly in Europe. Several new journals, such as Supply Chain Management, Journal of Chain and Network Science, have devoted considerable space to agricultural issues. Again, a comparative approach can be particularly valuable. Recent U.S. and European research projects have developed in this direction. ${ }^{4}$

\footnotetext{
${ }^{4}$ European examples include the project on quality control and organizations (Raynaud, Sauvée, and Valceschini), the SUSCHAIN (Marketing Sustainable Agriculture: An Analysis of the Potential Role of New Food Supply Chains in Sustainable Rural
}

Although still in progress, these studies highlight several reasons why networks are more highly developed in Europe than in the United States. The first is path dependence. The persistence of small farms throughout the EU, and particularly in France, Germany, and Italy (the three largest producers), results from history and geography, and from traditional rules regulating the transmission of land. Second, the agricultural policy environment established by the EU and the largest European countries in the 1960s and 1970s to smooth the transition from traditional to modern agriculture has encouraged the formation of networks, some of which are officially promoted and supported (e.g., in France or Italy). Third, as processors and distributors have become larger and have increased their requirements for quality, small producers have established and maintained networks to improve their bargaining position. Fourth, new regulations regarding quality and increased pressure from consumers for quality certification and identity preservation have given producers additional incentive to coordinate their processes. Fifth, the increase in global trade and the corresponding need to coordinate with producers or distributors in other countries and regions, and to deal with many layers of public authorities, have also contributed to the movement toward networking.

\section{Some Critical Issues}

The diversity of contracts and other organizational arrangements observed across countries and regions, as well as recent changes in how these arrangements are governed, raises several problems. Agricultural production is embedded in various and changing institutional environments, yet producers compete in increasingly global markets. At least two issues deserve particular attention and need a comparative approach that we, at ATOM and CORI, are developing in cooperation with other research centers.

Development) project associating seven European partners on the food supply chain-issue, the DOLPHINS (Development of Origin Labelled Products: Humanity, Innovation and Sustainability) project on the development of origin labeled products, and several projects coordinated by KLICT (Ketennetwerken, Clusters, and ICT), a Dutch organization. A U.S. example is a CORI survey of corn and soy producers' attitudes toward processors, analyzing whether variation in "trust" can be explained by processor size, ownership, and other characteristics. 


\section{Are Networks a Stable Mode of Organization?}

As described above, agricultural processes are increasingly vertically integrated, while farm ownership remains widely dispersed and farming remains a fairly decentralized activity. We interpret the development of network organizations as a tentative response to this imbalance. Are networks a stable mode of organization, or are they merely a transitional form, eventually giving way to consolidation and corporate ownership at the producer level? Similarly, do the new generation cooperatives described above represent a new type of cooperative or the beginning of the end of the cooperative structure itself?

Much more research is needed to answer these questions. First, we know little about the efficiency of networks relative to more integrated firms. There is obviously a greater need for tight coordination, and formal contracts are difficult to design and implement given agriculture's unique characteristics of seasonality and uncertainty. Second, most networks not only coordinate the marketing of their output but also pool significant resources. As a result, efficient rules for sharing returns among network members are difficult to design and implement. Unfortunately, we know little about the sharing rules used in various networks. Third, given agriculture's unique regulatory environment, we need to examine if networks are mainly the result of government policy rather than an efficient means of reducing transaction costs that could be effectively imitated in developing economies.

\section{Policy Issues}

These new forms of organization raise a dilemma for agricultural policy makers. On the one hand, regulators are concerned with increasing concentration in the processing and distribution sector and tightly coordinated producer networks appear to counterbalance that concentration. On the other hand, tightly coordinated groups of legally independent firms look like cartels. As Williamson has emphasized, competition authorities tend to take an "inhospitable" approach to such nonstandard contractual arrangements. Recent debates within some competition agencies suggest an increasing awareness of this dilemma, though decisions tend to support the conventional wisdom, which is based on a strong distinction between markets and integrated firms.
Reexamining competition policy through the lens of transaction cost economics is an important item on our research agendas.

\section{Summary and Conclusions}

The organization of food and agriculture, like that of other sectors of the economy, is tightly embedded in its institutional environment. These background conditions should not be regarded merely as constraints that hamper modernization. They also create incentives for the discovery of more efficient modes of organization. Comparing firms across different institutional environments to see what settings facilitate organizational innovation and what settings hamper it contributes dramatically to our understanding of the dynamics of a market economy. We regard the agrifood sector as an exceptional setting for studying these issues.

\section{References}

Allen, D.W., and D. Lueck. The Nature of the Farm: Contracts, Risk, and Organization in Agriculture. Cambridge: MIT Press, 2003.

Cook, M.L. "The Future of U.S. Agricultural Cooperatives: A Neo-Institutional Approach." American Journal of Agricultural Economics 77(1995):1153-59.

Frank, S., and D. Henderson. "Transaction Costs as Determinants of Vertical Coordination in the U.S. Food Industries." American Journal of Agricultural Economics 77(1992):94150.

Hendrikse, G.W.J., and J. Bijman. "Ownership Structure in Agrifood Chains: The Marketing Cooperative." American Journal of Agricultural Economics 84(2002):104-19.

Joskow, P.L. "Vertical Integration." In C. Ménard and M. Shirley, eds. Handbook of New Institutional Economics. Norwell: Kluwer, in press.

Klein, P.G. "Make or Buy Decisions: Lessons from Empirical Studies." In C. Ménard and M. Shirley, eds. Handbook of New Institutional Economics. Norwell: Kluwer, in press.

Knoeber, C. "A Real Game of Chicken: Contracts, Tournaments, and the Production of Broilers." Journal of Law, Economics and Organization 5(1989):271-92.

La Porta, R., F. López-de-Silanes, and A. Shleifer. "Corporate Ownership Around the World." Journal of Finance 54(1999):471517. 
Levy, B., and P. Spiller, eds. The Institutional Foundations of Regulatory Commitment. Cambridge: Cambridge University Press, 1993.

Martinez, S.W. "A Comparison of Vertical Coordination in the U.S. Poultry, Egg, and Pork Industries." Current Issues in Economics of Food Markets, Agriculture Information Bulletin No. 747-05, U.S. Department of Agriculture, Economic Research Service, 2002.

Martinez, S.W., and A. Reed. From Farmers to Consumers: Vertical Coordination in the Food Industry. Washington DC: U.S. Department of Agriculture, ERS Agricultural Economics Report 720, 1996.

Mazé, A. "Retailer's Branding Strategy: Contract Design, Organizational Change, and Learning." Journal of Chain and Network Science 2(2002):33-45.

Ménard, C. "On Clusters, Hybrids and other Strange Forms: The Case of the French Poultry Industry." Journal of Institutional and Theoretical Economics 152(1996):154-83.

Raynaud, E, L. Sauvée, and E. Valceschini. "Quality Strategies and Producers' Organization in the European Agro-Food
Sector: Competition Policy and Consumer Information." Working Paper, INRA. 2002.

Roe, M. "The Institutions of Corporate Governance." In C. Ménard and M. Shirley, eds. Handbook of New Institutional Economics. Norwell: Kluwer, in press.

Royer, J., and R. Rogers, eds. The Industrialization of Agriculture: Vertical Coordination in the U.S. Food System. Aldershot: Ashgate Publishers, 1998.

Sauvée, L. "Effectiveness, Efficiency, and the Design of Network Governance." Proceedings of the Fifth International Conference on Chain Management in Agribusiness and the Food Industry. In J.H. Trienekens and P.J.P. Zuurbier, eds. Wageningen, Netherlands: Wageningen University Press, 2000.

Shirley, M., and C. Ménard. "Cities Awash." In M. Shirley, ed. Thirsting for Efficiency: The Economics and Politics of Urban Water System Reform. New York: Elsevier, 2002.

Williamson, O.E. The Economic Institutions of Capitalism. New York: Free Press, 1985. 